\title{
О.Э. Хазанова
}

Московский педагогический государственный университет, 119991 г. Москва, Российская Федерация

\section{Отражение стиля языковых систем в Словаре английского языка Сэмюэля Джонсона (1755) и Словаре Академии Российской (1789-1794)}

В статье рассматриваются стилистические особенности языковых систем русского и английского языков по данным Словаря английского языка С. Джонсона и Словаря Академии Российской (XVIIIв.), заложивших основы английской и русской национальных лексикографий. Сравнение основных литературных источников словарей и лексикографических приемов, присущих этим словарным традициям, показало значительные различия в стиле двух языковых систем, которые отражаются на национальном менталитете, особенностях восприятия родного и иностранного языков и преподавании этих языков.

Ключевые слова: стиль языка, языковая система, Словарь английского языка С. Джонсона, Словарь Академии Российской, литературные источники словаря, лексикографические приемы, этимология, заимствования

ДЛЯ ЦИТИРОВАНИЯ: Хазанова О.Э. Отражение стиля языковых систем в Словаре английского языка Сэмюэля Джонсона (1755) и Словаре Академии Российской (1789-1794) // Рема. Rhema. 2019. № 4. C. 86-107. DOI: 10.31862/25002953-2019-4-86-107 


\section{O. Hazanova}

Moscow Pedagogical State University, Moscow, 119991, Russian Federation

\section{Style of the language systems as reflected in A Dictionary of the English Language by Samuel Johnson (1755) and A Dictionary of the Russian Academy ('Slovar' Akademii Rossiyskoy', 1789-1794)}

The article considers some stylistic aspects of the Russian and English language systems based on A Dictionary of The English Language... by Samuel Johnson, and A Dictionary of The Russian Academy ('Slovar Academii Rossiyskoy), $18^{\text {th }}$ C., that laid a foundation of the British and Russian national lexicography. A comparison of major literary sources of the dictionaries and approaches applied in these lexicographic traditions reveals significant differences between the styles of the two language systems, which has an impact on the national mentalities, ways of perception of a mother tongue and a foreign language, as well as methods of teaching the two languages.

Key words: style of the language, language system, A Dictionary of the English Language by S. Johnson, A Dictionary of The Russian Academy ('Slovar Academii Rossiyskoi'), literary sources of the dictionary, lexicographic approaches, etymology, loan words

FOR CITATION: Hazanova O. Style of the language systems as reflected in A Dictionary of the English Language by Samuel Johnson (1755) and A Dictionary of the Russian Academy ('Slovar' Akademii Rossiyskoy', 1789-1794). Rhema. 2019. No. 4. Pp. 86-107. (In Russ.) DOI: 10.31862/2500-2953-2019-4-86-107

Остроумное замечание Ф. де Соссюра о том, что все люди, говорящие на одном языке, похожи, «как экземпляры одного словаря», связано с понятием стиля языка, которое подразумевает совокупность исторически отобранных лексических элементов и стандартных вариантов их сочетаемости, хранящихся наподобие оттиска в умах всех 
пользователей языком, благодаря чему между ними возможна коммуникация [Языкознание, 1998, с. 494]. Понятие «стиль языка» противополагается понятиям «стиль речи», «стиль автора», «стиль произведения» как универсальное - индивидуальным. Первое - основание для языковой деятельности всех говорящих на языке; другие - творчество отдельных языковых личностей на фоне стиля языковой системы. Если продолжить соссюровскую метафору, то окажется, что народы, говорящие на разных языках, отличаются настолько, насколько отличаются их словари.

В филологии под «стилем языка», или «стилем языковой системы», обычно понимают особенности литературных источников словаря и характер лексикографического описания языка. Языковые системы письменных литературных национальных языков основаны на лингвистическом описании текстов некоторого числа авторов, признанных образцовыми, которые составляют основу словаря языка. Исследование образцовых текстов формирует предпосылки для построения словаря языка и, как правило, предшествует ему.

Сравнение основных источников словарей русского и английского языков и лексикографических приемов, присущих этим словарным традициям, показывает значительные различия в стиле двух языковых систем, которые отражаются на национальном менталитете, особенностях восприятия родного и иностранного языков [Хазанова, 2000, с. 139, 140].

В статье стиль английского и русского языков рассматривается на материале словарных изданий XVIII в., заложивших основы национальных лексикографий и повлиявших на стиль языковых систем этих языков в последующие столетия - словаря английского языка Сэмюэля Джонсона (1755 г.) и Словаря Академии Российской (1789-1794).

Обращение к сопоставительному описанию русского и европейских языков характерно для отечественной филологии. В работах о русском языке в компаративном европейском контексте XVIII-XIX вв. на первый план традиционно выступает его сопоставление с французским в силу влияния, которое французский язык и словесность оказали на развитие русского языка и литературы, а также на становление русской лексикографии, в этот период (см., например [Захарова, 2009]). Для $\mathrm{XX}-\mathrm{XXI}$ вв. более значимой становится культурная и филологическая параллель русский язык / английский язык. Сопоставительный анализ этих языков ведется исследователями в разных аспектах: лингвистическом, поэтическом, риторическом ${ }^{1}$.

\footnotetext{
${ }^{1}$ См., например, книгу В.Д. Аракина «Сравнительная типология английского и русского языков» [Аракин, 2005]; анализ английских и русских риторик в «Теории риторики» Ю.В. Рождественского [Рождественский, 1997].
} 
Изучение стилей языковых систем русского и английского языков, сформированных национальными лексикографиями, могло бы дополнить и уточнить сопоставительную картину. Оно целесообразно по ряду оснований. Культурным: ввиду того, что английский и русский языки выступают языками интернационального общения и конкурируют, то явно, то скрыто, на протяжении последних двух столетий; при этом полемика протекает не только в политической плоскости, но касается и лингвистического, литературного, стилистического потенциала этих языков, который в самой общей форме отражен в национальных лексикографических традициях. Дидактическим: поскольку английский язык занимает второе, после русского, место в российском школьном и университетском образовании, необходимо сравнительное изучение этих языков с точки зрения национальных доминант и приоритетов стилей их языковых систем с целью эффективного преподавания.

Уже предварительный взгляд на Словарь русского языка Академии Российской (САР) и Словарь английского языка С. Джонсона выявляет ряд общих черт: единые хронологические рамки их создания - вторая половина XVIII в., т.е. достаточно поздно по сравнению со словарями других европейских языков ${ }^{2}$; нормирующий характер по отношению к предмету описания; прескриптивную направленность по отношению к пользователям; примерно одинаковый объем словника - около 43 тысяч единиц.

Сопоставление САР (плода коллективного творчества российских академиков) со словарем одного автора, С. Джонсона, объясняется исторически: отсутствием у англичан академии. Вопрос о создании академии, по примеру Флорентийской и Парижской, для упорядочения английского языка неоднократно поднимался английскими интеллектуалами в начале XVIII в. К этому призывали Дж. Драйден, Дж. Свифт, Дж. Аддисон и другие. Королева Анна благоволила проекту, однако после ее смерти популярность его пошла на убыль. Создание самого авторитетного словаря в истории английского языка было предложено известному литератору Сэмюэлю Джонсону, написавшему словарь за семь лет [Германова, 2014, с. 61-62]. Задачи, которые стояли перед европейскими и российскими академиками, - очистить язык от всего, что нарушает его красоту и ясность, выработать языковую норму для общего употребления - были осуществлены на английской почве С. Джонсоном в его Словаре английского языка.

\footnotetext{
${ }^{2}$ Ср. время издания толковых словарей новых европейских языков: итальянского 1612 г., французского - 1694 г., испанского - 1726-1739 гг.
} 
Помимо указанных выше сходных черт, характерным для двух словарей является тот факт, что их составители исходили из ситуации взаимодействия родного языка с классическим - русского с церковнославянским и английского с латынью. Однако способ функционирования классических языков в двух культурах на момент составления словарей во многом отличался.

B XVI-XVII вв. латынь, обогатив английский язык множеством понятий и терминов, утратила свой статус языка религии ${ }^{3}$ и науки. В течение нескольких столетий, до создания словаря С. Джонсоном, на английском языке, впитавшем латинизмы, были написаны тысячи литературных произведений, включая сотни блестящих образцов философской, научной и художественной прозы и поэзии. Несмотря на успехи английского языка, в XVIII в. к латыни продолжали относиться как к эталонному, «идеальному» языку, источнику вдохновения для английских интеллектуалов. Так, известны попытки Дж. Драйдена и Ф. Бэкона перевести собственные произведения с английского языка на латинский и обратно на английский с целью усовершенствовать их стиль [Lynch, 2009, c. 42-46]. На фоне латыни английский язык признавался общественным мнением слишком неупорядоченным и неэлегантным.

В России первая треть XVIII в. была последним периодом славянорусского двуязычия, когда старославянский и русский языки применялись в разных функциональных сферах. На старославянском велось богослужение, писалась церковная литература (за исключением житий), высокие поэтические жанры (оды, героические поэмы). Русский язык использовался в деловой письменности, прозаических литературных жанрах (летописях, художественных переводах) [Гухман, 1970 , с. 522-524]. Постепенно в написанных по-славянски и переведенных на славянский язык религиозных и научных трудах усиливалось взаимодействие славянского языка с русским. Примерно с 30-40-х гг. XVIII в. русский язык встал на путь сознательного смешения лексики разного происхождения, которое завершилось в Англии примерно на полтора столетия ранее. Сфера книжно-славянского языка сузилась, он уже не составлял цельной системы, а его употребление в дальнейшем ограничилось религиозной сферой. С середины XVIII в. церковно-славянский становится стилистической категорией, входящей в литературный русский язык как стилистическое средство [Захарова, Петрова, 2002, с. 25, 26].

3 Латынь сохраняла статус «священного языка» в Римской католической церкви Англии. В англиканских церквях Библия читалась на английском, в переводе, осуществленном в 1604-1611 гг. при поддержке короля Иакова. 
Дихотомии английский/латынь и российский/церковнославянский имели и разное идеологическое содержание. Церковнославянский язык всегда связывался в русской культуре с национальным началом, поэтому церковнославянско-русское двуязычие проецировалось составителями САР на литературный язык в целом, тогда как латинские заимствования в английском языке соотносились с определенными видами слова, прежде всего, религиозными, юридическими и научными.

При всем различии языковых ситуаций в России и Англии середины XVIII в. российские академики и Сэмюэль Джонсон ставили перед собой сходную задачу: не только лексикологическое, но и стилистическое осмысление национального литературного языка на фоне классического. Интерес составителей к языковому стилю выразился в принципах отбора источников словника, внимании к истории слов, поиске баланса между заимствованной и исконной лексикой, разработке словарных помет, подходах к экземплификации лексических единиц. Можно сказать, что на страницах словарей впервые сознательно формировался стиль языковых систем английского и русского языков.

\section{1. Формирование стиля английского языка в словаре Сэмюэля Джонсона, 1755 г.}

На момент подписания договора о создании словаря между С. Джонсоном и консорциумом лондонских издателей в 1746 г., английский язык характеризовался образованной частью общества как corrupt, unruly, unrefined, barbarous, т.е. 'испорченный', 'неупорядоченный', 'грубый', 'варварский' [Crystal, 2002, с. 222]. Наступил тот перелом в языковом сознании англичан, когда стало очевидно, что «не писатели пишут плохим языком, а язык сам по себе плох» [Lynch, 2009, с. 43].

В предисловии к своему труду С. Джонсон заявляет: «Я предпринимаю попытку... составления словаря английского языка, который, хотя и используется для создания всех родов литературы, развивается с невероятной энергией под влиянием случая, покоряется тирании времени и моды и беззащитен перед искажениями... Я нахожу мой язык богатым, но неупорядоченным; энергичным, но без правил» ${ }^{4}$ [Johnson, 1755].

Приведем полное название словаря д-ра Джонсона: A Dictionary Of The English Language: In Which The Words are deduced from their Originals, And Illustrated in their Different Significations By Examples from the best Writers. To Which Are Prefixed, A History of the Language, And An English Grammar. By Samuel Johnson, A.M. In Two Volumes (рис. 1).

\footnotetext{
4 Здесь и далее переводы автора статьи.
} 


\section{$\mathbf{A}$ \\ D I C T I O N A R Y \\ O $\mathrm{F}$ T H}

E NGLISH LA N G UA E :

I N WICH

The WORDS are deduced from their ORIGINALS,

$A$ N D

ILLUSTRATRD in their DIFFERENT SIGNIFICATIONS

B $\mathbf{Y}$

EXAMPLES from the beft WRITERS.

TO WHICH ARE PREFIXRD,

A H I TOR Y of the L A N U A G E,

$A$ N $D$

AN E NGLISH GRAMMAR.

BY S A MUEC JOHNSON, A.M.

IN TWO VOLUMES;

V O L. I.

Рис. 1. Фрагмент титульного листа второго издания словаря С. Джонсона

Перевод заглавия: «Словарь английского языка, в котором слова толкуются с точки зрения их происхождения и проиллюстрированы в их разных значениях примерами из лучших писателей, чему предпосланы история языка и английская грамматика. Составлен Сэмюэлем Джонсоном. В двух томах. Лондон». В самом названии словаря С. Джонсона заложена направленность на стилистическое осмысление языковой системы. Именно источники заимствования слова и способы его употребления в литературных текстах призваны помочь пользователям словаря осуществить выбор из 'неограниченного многообразия' (boundless variety) английского лексикона и найти стилистически верные 'способы выражения' (modes of expression).

Задача стилистического описания английской лексики отразилась и в том принципе, по которому д-р Джонсон составлял словник: selection rather than collection, т.е. «отбор вместо собирания» слов. В предисловии к своему труду он подчеркивает, что намерен основываться на литературном текстовом материале, а не на показаниях предшествующих словарей: «Слова надо искать там, где они употребляются» 
(т.е. в письменных текстах) и «Я опустил многие из них (слов из более ранних словарей - O.X.), ибо я никогда не встречал их в текстах» [Johnson, 1755]. Документальным свидетельством существования слова в языке для Джонсона было обнаружение слова в литературных текстах влиятельных авторов. В результате такого подхода Словарь д-ра Джонсона содержал на 25 тысяч слов меньше, чем словарь английского языка, составленный его современниками Дж. Скоттом и Н. Бейли.

О своем понимании того, каким должно быть соотношение латыни и английского языка в словаре, Джонсон заявляет в Предисловии: «Я приступаю к работе со свойственной ученому почтением к древности и вниманием грамматика к гению собственного языка» [Там же]. Он пишет о влиянии французского язык: «Наш язык на протяжении почти столетия по стечению разных обстоятельств постепенно отходит от своей изначальной германской природы и отклоняется в сторону галльской структуры и фразеологии, чего нам следует избегать, полагаясь на древность как основу стиля и допуская из добавлений последнего времени лишь те, которые могут восполнить действительный недостаток в словах; такие, которые уже адаптированы гением нашего языка и соответствуют фразеологии родного языка» [Там же]. Так романские источники английского языка оказываются четко разделенными относительно их роли в современном автору словаря английском языке (хотя Джонсон и замечает, что часто невозможно определить, из латинского или французского языка заимствовано слово).

Словарные дефиниции многих германских лексем в словаре сформулированы на основе латыни, как, например, фразеологические глаголы, которые объясняются посредством латинских синонимов: to bear out to justify; to set off - to embellish и т.п. Джонсон поясняет, что учитывая многовековое присутствие латыни в Англии, такое соседство не осложняет, но облегчает понимание.

Значительный пласт латинской лексики в словаре представлен научной терминологией. Джонсон привлекает термины ремесел и искусств из научных трудов и технических словарей, при этом критерием отбора выступает не частотность использования слова, но авторитетность источника заимствования. Таким же образом из философских сочинений им извлекаются перспективные термины - «кандидаты или испытуемые», т.е. слова, обладающие, по мнению Джонсона, терминологическим потенциалом. Выступая в роли терминотворца, переосмысливающего первичные значения слов, Джонсон оставляет окончательное утверждение изобретенных терминов будущим диалектикам. Сетуя на недостаточность научного и технического словника, он, тем не менее, отказывается заимствовать термины непосредственно из речи 
коммерсантов, ремесленников, моряков ввиду «грубости» возможных находок, «не достойных сохранения в словаре» [Johnson, 1755]. Освященность литературным авторитетом и литературным текстом - яркая черта стиля английского языка, формируемого на страницах словаря его создателем.

Иллюстрируя отобранные слова, С. Джонсон следует принципам изящества и элегантности, которые складывались в ходе исторического развития английского языка на фоне романских и отразились в литературных текстах. В Плане словаря (1747 г.) он пишет: «Я вознамерился консультироваться у лучших писателей...», поскольку «слава любого народа происходит, главным образом, от его авторов» [Johnson, 1747]. Джонсон заимствует цитаты из литературных текстов, начиная с Елизаветинской эпохи и современных ему авторов: «Из текстов авторов, которые явились во времена Елизаветы, можно сформировать речь, соответствующую всем целям и критериям элегантности». (Под целями использования речи подразумеваются функциональные стили языка) [Johnson, 1755]. Так читателям словаря явился английский язык последних двухсот лет его развития: язык периода расцвета английской литературы, а, значит, обработанный и элегантный, еще не устаревший и внятный обществу на момент выхода словаря.

Согласно данным сайта, осуществляющего статистическую обработку словаря Джонсона (ко времени написания данной статьи оцифрована одна десятая часть корпуса), в качестве наиболее влиятельных Джонсон цитирует следующих авторов:

1) У. Шекспир (процитирован в 1101 статье словаря);

2) Дж. Драйден (в 788 статьях);

3) Дж. Милтон (в 449 статьях);

4) Дж. Аддисон (в 408 статьях);

5) Ф. Бэкон (в 396 статьях);

6) А. Поуп (в 393 статьях);

7) Дж. Свифт (в 306 статьях);

8) Книги Библии (в 293 статьях);

9) Дж. Локк (в 269 статьях);

10) Э. Спенсер (в 254 статьях) [Там же].

В Плане к словарю Джонсон объяснял, что включение писателя или поэта в словарь может считаться приглашением к чтению его произведений ${ }^{5}$ [Johnson, 1747]. Авторы, чьи строки оказались в словаре

\footnotetext{
${ }^{5}$ Следующей после словаря большой работой С. Джонсона стало десятитомное «Жизнеописание лучших английских поэтов» (The Lives of the Poets, 1779-1781), в котором он выступает как биограф и критик, а также вводит новые термины в систему национальной словесности, которые впоследствии стали общепринятыми.
} 
Джонсона в качестве иллюстраций, позднее составили канон английской литературы, что подтверждает точность лингвистического и стилистического отбора автора словаря.

Джонсон дифференцирует литературные иллюстрации, выделяя не только разные значения слова, но и высвечивая оттенки значений и типы стилистической сочетаемости. Он проводит читателя словаря через ряды тщательно выстроенных лингвистических и стилистических оппозиций. Одна и та же лексическая единица оказывается окружена цитатами из древних и «элегантных современных» авторов, из более и менее авторитетных литературных источников; в высоком, низком и нейтральном регистрах; в простых и сложных синтаксических структурах; в «прозрачных» и «туманных» контекстах. Такая стилистическая «огранка» слова - часть колоссальной работы Джонсона над стилем языковой системы. Он пишет: «Слово, сколько бы раз оно не повторялось, возникает в окружении новых элементов и в разных сочетаниях, и каждая цитата способствует стабильности или обогащению нашего языка. <..> Когда различные комбинации с одним и тем же словом предъявлены вместе, легко предпочесть правильную, и я зачастую пытаюсь направить этот выбор» [Johnson, 1755].

Однако авторское употребление не является окончательным вердиктом слову в словаре. Выступая в роли диалектика по отношению к авторскому слову, Джонсон вводит около 90 (!) стилистических помет для маркировки лексических единиц, среди которых: barbarian (варварское), bad (неправильное), cant (сленг), corrupt (искаженное), harsh (резкое, неприятное), ungrammatical (ошибочное), vulgar (вульгарное), coarse (грубое), elegant (элегантное), graceful (изящное) и т.д. [Ступин, 1986, с. 66-78]. Из характера помет в словаре очевидно стремление автора освободить английский язык от просторечных и грамматически неправильных элементов, противопоставив им понятия лингвистически и эстетически совершенные и рекомендуемые к употреблению.

В Предисловии к словарю Джонсон делает прогноз относительно будущего английского языка, сформулированный в виде серии вызовов, с которыми язык неминуемо столкнется в ходе своего развития. Джонсон показывает, как рост объема информации в обществе и развитие функциональных подсистем языка повлияет на динамику английской лексики и изменит стилистический облик языковой системы в целом. Его прогноз описывает:

- распространение профессиональных и коммерческих жаргонов, смешанных с иностранными языками, их вхождение в общий язык; - увеличение числа новых слов ввиду умножения знаний и, соответственно, переход других лексических единиц в разряд архаизмов; 
- ввиду развития науки отвлечение все большего числа слов от их прямых значений и приобретение метафорических, т.е. возникновение новых терминов как результата третичной номинации: «Поэтические тропы будут постоянно вторгаться, и метафорический смысл станет повседневным»;

- ввиду изобилия словаря возможность «капризного выбора», когда одним словам будет оказано предпочтение, а статус других будет понижаться: «переменчивая мода» будет навязывать употребление новых слов или приводить к расширению их семантики;

- подчинение письменной речи устной посредством художественного слова: «безграмотные писатели то и дело будут становиться популярными благодаря любви публики и, не зная исходных значений слов, станут использовать их с разговорной фривольностью»;

- усиление регуляторных мер по отношению к языку со стороны общества: «по мере распространения хороших манер» некоторые выражения будут рассматриваться «как грубые и вульгарные, а другие как излишне официальные и церемонные»;

- «смешение двух языков всегда будет производить третий, отличный от них обоих, и языки всегда будут смешиваться там, где основное образование и выдающиеся свершения духа осуществляются на классическом или иностранном языке»;

- изменения фразеологии и идиоматики благодаря большому числу переводов с других языков: «Отдельные слова могут входить в язык тысячами, оставляя ткань языка нетронутой, но новая фразеология меняет не просто один камень в колонне, но сам ордер колонны» [Johnson, 1755].

Предсказания Сэмюэля Джонсона реализовались в языковой системе английского языка в последующие столетия, что нашло отражение в словарях английского языка традиций Oxford и Webster, изданных в XIX-XX вв. Одновременно его прогноз носит универсальный характер по отношению к стилю языковых систем, поскольку показывает, что стиль языка зависит, с одной стороны, от влияния иностранных языков, с другой - от взаимодействия функциональных стилей в системе языка, и от регламентирующих устремлений общества по отношению к стихийному развитию языка - с третьей.

\section{2. Формирование стиля русского языка в Словаре Академии Российской, 1789-1794}

В Словаре Академии Российской (САР), составленном под руководством Е.Р. Дашковой и покровительством Екатерины II, предметом описания стал «славенороссийский язык». Термин «славенороссийский» 
был введен В.К. Тредиаковским для названия русского литературного языка с целью продемонстрировать единство церковнославянского и русского языков, «их субстанциональную общность». Ранее «славенороссийский» обозначало церковнославянский. Дифференцировав термины, Тредиаковский подчеркнул внутреннюю связь между церковнославянским и русским литературным языком, которые понимались им как один язык, реализующийся в церковной и гражданской сфере. М.В. Ломоносов, напротив, не считал церковнославянский язык предком русского языка, рассматривая их объединение как результат смешения двух разных языков, т.е. подчеркивал «гетерогенную, макароническую» природу русского литературного языка [Успенский, 1994, с. 137-147].

Составители САР следовали ломоносовской точке зрения. Они пишут в предисловии: «Этот общий славенороссийский язык, помимо основы в виде славенского языка, великое множество содержит слов собственно русских, по свойству коих некоторые из славенского языка почерпнутые иное окончание, иное образование, а другие и новый смысл получили» [CAP, 1789-1794, с. VI]. Выражения «общий язык», «собственно русских», «из славенского языка почерпнутые» указывают, что составители САР рассматривают церковнославянский и русский как два языка, каждый со своей особой ролью в «общем» языке: церковнославянский исторический и философский фундамент, русский же обладает демиургическим потенциалом, он - активное преобразующее начало в области морфологии и семантики. Академики ставят себе задачу «вникать в тот и другой язык с возможною точностию; ибо от соединения их зависит обилие, сила, важность и красота языка ныне употребимого» [Там же]. Слияние стихий разных языков, имевшее место в истории английского языка до XVII в. и давшее обильные литературные плоды к моменту составления Словаря С. Джонсоном в XVIII в., происходило на глазах авторов Словаря Академии Российской и закреплялось в словаре их собственной волей.

В ряду межъязыковых сопоставлений, проводимых в предисловии к САР, - русский/славенский; славенский/греческий; русский/греческий; русский / другие современные славянские языки - особое место принадлежит взаимодействию родного языка с греческим. Эстетические качества славенороссийского языка связываются авторами словаря со стилем и эстетическим идеалом священных текстов на греческом языке, переведенных на церковнославянский. Академики проецируют на стиль церковнославянского и русского языков и саму духовность священных текстов на греческом, а также греческие принципы словообразования и орфографии, подчеркивая тем самым достоинства славенороссийского языка как наследника греческих учености, богословия 
и языкового стиля, когда от перевода священных книг «на славенский язык пробрел сей обилие, важность, силу, краткость в изображении мыслей, удобность к сложению слов и другия красоты языка греческого» [CAР, 1789-1794, с. VII]. Набор идеальных, в представлении академиков, качеств русского языка «обилие, красота, важность и сила» повторяется в предисловии САР троекратно [Там же, с. III, VII, VIII]. (Для сравнения: излюбленные эпитеты С. Джонсона о стиле английского языка - «элегантный», «изящный», что связано с ориентацией его словаря на эстетику светских литературных источников).

Авторы САР указывают на коммуникативные преимущества, привносимые церковнославянским языком: из того факта, что греко-российская церковь «во всех племенах славенских единым языком славословит имя Божее», русские люди, в отличие от европейцев, во-первых, «разумеют» древние книги, написанные по-церковнославянски; во-вторых, понимают «другие славенские наречия», т.е. современные славянские языки [Там же, с. VII]. Таким образом присутствие старославянского страта в составе литературного русского языка оказывается мотивированным как в диахронии, так и на синхронном срезе.

Выбор источников для словника САР также ориентирован по двум осям: «собрать всевозможные слова в употреблении бывшие и ныне находящиеся» [Там же, с. VIII]. Академия решает дополнить существующие печатные и письменные «собрания» слов лексикой из церковных книг, лучших светских сочинений, летописей, древних и новейших законодательств, записок путешественников, научными и профессиональными выражениями, тем самым раздвигая границы словаря. Особое место среди литературных источников отводится церковным книгам, богослужебным и гомилетического жанра, и летописям XII-XVII вв.: «Заслуживают особливого примечания Маргарит, Ирмолог, Октоих, Триодь Постная, Триодь Цветная, Минея Праздничная, книга Назианзина, беседы Златоустовы на Новый Завет, Несторов Летописец, Летописцы Архангелогородский и Новгородский» [Там же]. Круг церковнославянизмов в словаре оказался гораздо шире реально функционирующих в высоком и среднем слове русской письменности второй половины XVIII в. Это «расширение» было одновременно и «углублением», учитывая его историческую направленность.

В отличие от С. Джонсона, российские академики не располагали обширным корпусом художественной и философской литературы на родном языке. Н.М. Карамзин писал: «Италия, Франция, Англия, Германия славились уже многими великими Писателями, еще не имея Словаря: мы имели церковныя, духовныя книги; имели Стихотворцев, 
Писателей ${ }^{6}$, но только одного истинно классическаго (Ломоносова), и представили систему языка, которая может равняться с знаменитыми творениями Академии Флорентийской и Парижской» [Карамзин, 1964, c. 233].

Другой отличительной стилистической чертой САР стало внимание к русскому просторечию: составители фиксируют лексические сочетания и фразеологизмы «речи простого народа», с которым «никакой народ не может равняться обилием пословиц и поговорок...» [CAР, 1789-1794, с. XIV]. Оставив в стороне паремии «низкие» по форме и содержанию, они включают те пословицы и поговорки, которые «кратки, заключают в себе острый смысл или ясное поучение» [Там же]. САР представляет собой, по выражению исследователей, «сокровищницу народной и разговорной речи» [Чернышова, 2002, с. 15].

Отбор из полученного «обилия» материала для словника САР был основан, с одной стороны, на фактах употребительности и распространенности слова, а с другой - на принципах пуризма, определяемого идеей самодостаточности «славенороссийского языка». За пределами САР остались:

- «слова и речения наук и художеств, которые не входят в общее употребление...»;

- «все слова и речи благопристойности противныя»;

- «все слова старинные, вышедшие из употребления», за исключением историзмов, описывающих народные обычаи и обряды, и тех, которые представляют собой словообразовательные основы для современных слов (Для сравнения: С. Джонсон усматривал повод для «возрождения» устаревшего слова в его «силе» или «красоте», или в использовании его современными авторами);

- «все областные слова», за исключением тех, которые «ясностью, силой и краткостью могут служить к обогащению языка»;

- «все иностранные слова, введенные без нужды и которым равносильные российские и славянские находятся» [САР, 1789-1794, с. IX]; из заимствований в САР включены «еврейские и греческие слова, принятые в священных книгах», иноязычные звания, титулы и т.п. [Там же, с. VIII, XIX, XIV].

Две последние группы слов поставлены в САР в отношения взаимозаменяемости. Ввиду пуристской позиции составителей в словарь было

\footnotetext{
${ }^{6}$ Почти одновременно с изданием САР, в 1772 г., был издан первый «Опыт исторического словаря о российских писателях» Н.Н. Новикова, который позволяет выделить наиболее авторитетных литераторов на основании объема статей, им посвященных: Ф. Волков - 390 строк, Ф. Прокопович - 360 строк, М. Ломоносов - 330 строк, А. Кантемир - 320 строк, Амвросий - 256 строк, В. Тредиаковский - 240 строк.
} 
включено большое число диалектизмов, способных, по мысли авторов, заменить заимствования. САР далеко не полно отразил заимствования, датируемые XVIII в. Например, не были включены такие слова, как автор, агент, адвокат, акт, акцент, анархия, аппетит, которые имели активное употребление в языке, давали словообразовательные ряды и были зафиксированы в других лексикографических описаниях своей эпохи, в частности, в словаре А. Богдановича [Малышева, 2009, с. 167].

Для объяснения происхождения слова приводится указание на язык, к которому оно возводится. Внимание составителей САР к истории языка проявилось и в расположении слов корневыми гнездами, углубившем историко-грамматическую перспективу слова.

Составители САР прибегают к разным способам стилистического осмысления словесного материала. Стилистические пометы относят слово к одному из двух классов: связанному с церковнославянской традицией, пометы «сл.», «слав», или к стихии народного языка. По мнению исследователей, содержание помет «сл.», «слав.» - историческое или стилистическое - не вполне ясно и, вероятно используется в САР в обоих смыслах [Захарова, Петрова, 2002, с. 25-26]. Слова с такими пометами обычно снабжены иллюстрациями, выступающими в роли стилистических маркеров: «Присовокуплены, где нужда требовала, избранные примеры для показания различия слогов, где и какое слово употребляется, приведены примеры славенороссийские, то есть из книг церковных и лучших писателей светских, через что означается их употребление в высоком и красном слоге» [САР, 1789-1794, с. Х].

Характерно стилистическое распределение примеров для разных значений одного и того же славянского слова. Так, агнец, выступая в религиозных значениях - «дар Богу», «имя Иисуса Христа», «мученик», «часть просфоры», иллюстрируется цитатами из Ветхого и Нового Заветов, Апокалипсиса и церковных песнопений. Тогда как переносное светское его значение - «кроткий незлобивый человек», экземплифицировано «речением» от составителей, т.е. примером «рангом ниже».

Пометы предостерегающего характера, такие как «в просторечии или в разговорах употребляемое» (для экспрессивно-сниженной лексики разных социальных слоев и низких литературных жанров), «простонародное» (о речи необразованных сословий), «уничижительное», служат стилистическому уточнению лексики народно-разговорной речи [Малышева, 2009, с. 162-164]. Другие маркеры народного языка - помета «областное» и ареальные характеристики диалектизмов - помещены непосредственно в статьях, когда указывается, что слово употребляется «в Камчатке» или «у Козаков Уральских», или «в Поморье» и т.п. [Волынская, 2009, с. 42-46]. 
Таким образом, в САР стилистическая маркировка лексических единиц высокого стиля происходит посредством введения литературного примера; слова низкого стиля снабжены стилистическими пометами предостерегающего характера. Отсутствие единообразия в способах стилистической маркировки словесного материала, недостаточная разработанность стилистических помет, их односторонняя модальная направленность создают впечатление определенной стилистической свободы в САР. Возможно, это позволило Г.О. Винокуру сказать о словаре: «В нем нет прямо и открыто провозглашаемой нормы. Но в нем есть возможность угадывать тот идеал языкового употребления, по направлению к которому движутся составители словаря сквозь богато отражаемые им языковые противоречия своего времени» [Винокур, 1959 , c. 163].

«Идеалы языкового употребления» российских академиков и Сэмюэля Джонсона, отразившиеся в их словарях, суммированы ниже.

Общее в подходах к составлению двух словарей:

- нормирующий характер изданий, реализованный в лексикологическом и стилистическом аспектах; акцент на отборе (не просто собирании) слов и их стилистическом осмыслении;

- взгляд на национальный литературный язык как результат взаимодействия родного языка с классическим, который исторически является языком Священного писания и образования;

- привлечение литературных источников, включая Библию;

- наличие сведений о происхождении слов;

- пуристское отношение к современным заимствованиям;

- исключение обсценной лексики;

- наличие стилистических помет предостерегающего характера.

Особенности представления стилей языковых систем по данным словарей приведены в таблице 1 .

Приведенные различия можно обобщить следующим образом:

- для стиля русского языка, представленного в САР, характерен выраженный диахронический вектор (см. п. 1 и 4 табл. 1);

- САР как единый текст обладал более сильной духовной составляющей (см. п. 5);

- С. Джонсону удалось представить английский язык через собрание высказываний лучших умов Англии XVI-XVIII вв. (см. п. 6);

- в отличие от словаря С. Джонсона с его установкой на элегантный язык образованного общества, САР вовлек стихию народного языка и фольклор (см. п. 7);

- в САР в меньшей степени, чем в словаре С. Джонсона, проявляется прескриптивная модальность (см. п. 2, 3). 
Таблица 1

Различия в стиле языковых систем в Словаре С. Джонсона и Словаре Академии Российской

\begin{tabular}{|c|l|c|c|}
\hline \multirow{2}{*}{ o. } & \multicolumn{1}{|c|}{ Способы словарного описания } & $\begin{array}{c}\text { Словарь } \\
\text { Джонсона }\end{array}$ & САР \\
\hline 1 & $\begin{array}{l}\text { Гнездовой (словообразовательный) принцип } \\
\text { организации словника }\end{array}$ & - & + \\
\hline 2 & $\begin{array}{l}\text { Иллюстрации сочинены авторами словаря; } \\
\text { отсутствуют иллюстраций для части слов }\end{array}$ & - & + \\
\hline 3 & $\begin{array}{l}\text { Использование стилистических помет } \\
\text { и комментариев одобрительного, } \\
\text { рекомендательного характера }\end{array}$ & + & + \\
\hline & \multicolumn{1}{|c|}{ Литературные источники словаря } & + \\
\hline 4 & Древние тексты & - & + \\
\hline 5 & Религиозные тексты помимо Библии & + & + \\
\hline 6 & $\begin{array}{l}\text { Преобладание светских литературных } \\
\text { источников над духовными }\end{array}$ & - & + \\
\hline 7 & Фольклорные тексты и народный язык & & + \\
\hline
\end{tabular}

Так уже на ранних этапах формирования национальных лексикографических традиций видно принципиально различное отношение русских и британских составителей к включению в словарь национального языка элементов народного языка и фольклора, религиозных и светских литературных источников, научной лексики, что будет отражаться на ходе дальнейшего развития лексикографии на английском и русском языках и влиять на формирование стиля двух языков в последующие столетия.

\section{3. Особенности стиля языка в современных русских и английских словарях}

Английские словари британского и американского издательских домов Oxford и Webster и словари русского языка, изданные в XXXXI вв., показывают значительные различия в лексикографических подходах и фиксируют разные стилистические образы языковых систем.

Современная английская лексикография ограниченно пользуется фольклорными источниками. Значительная часть английских пословиц германского происхождения вытеснена из обихода клишированными выражениями из латыни, цитатами из Библии, крылатыми авторскими 
фразами Шекспира и других литераторов. В русском языке существуют многочисленные словари пословиц и поговорок.

Диалектизмы не включены в состав английских толковых словарей и не входят в состав английского литературного языка. В русской лексикографии диалектные слова собраны в четырехтомном труде В.И. Даля XIX в., широко представлены в современных общих словарях.

Научная терминология широко представлена в английских толковых словаря ${ }^{7}$ и в ограниченном количестве входит в состав общих словарей русского языка.

Одно из ключевых методологических различий русской и английской лексикографических традиций, повлиявших на стиль языковых систем, лежит в отношении к этимологизации слов в словарях. «Словарная этимология показывает, что все языки не просто развиваются из своего собственного ресурса создания новых слов, но обязательно вовлекают в этот процесс дополнительные слова из других языков: всякий развитой язык постоянно включает в себя заимствования. Включение заимствований раскрывается словарной этимологией и создает образ языка» [Рождественский, Блинов, 2005, с. 120].

Для английского языка заимствования всегда стилистически маркированы: толковые словари английского языка приводят этимологию, установленную или предполагаемую, для каждой лексической единицы. В русской лексикографии этимологические словари носят характер специальных, адресованных в первую очередь филологам, общие толковые словари этимологических толкований слов обычно не содержат. Это свидетельствует о «равноправии» коренных русских слов и заимствований из греческого, латинского, французского, польского, тюркских и других языков у современного носителя русского языка [Хазанова, 2000, с. 141].

Представленность этимологических толкований в словарях объясняется историческим типом заимствований: «диффузным» для русского языка, когда источники заимствования не подвергаются стилистическому регулированию, а сами заимствования возникают по мере необходимости в зависимости от характера языковых контактов; или целенаправленным, как это было в английском языке в результате Нормандского завоевания, когда английский язык несколько веков находился под сильным влиянием старофранцузского. Следует учитывать и тот факт, что развитие английского языка проходило под воздействием английской системы образования, сознательно ориентированной на классические

\footnotetext{
${ }^{7}$ См. на эту тему исследование о терминологической системе американского словаря «Webster» [Дорошенко, 1984].
} 
источники культуры, традиционное латинское образование. Латинизация английского языка в результате образовательной политики Англии в XV-XVI вв. оказала решающее влияние на его словарный состав, фразеологию, композиционные структуры, т.е. стиль языковой системы в целом [Рождественский, 2015, с. 184, 185]. «Благодаря этому английский язык, особенно в его письменной форме, сохраняет облик учености, а этимология латинских заимствований определяет их стилистическое использование в текстах, в том числе и современных (в частности, деловых)» [Рождественский, Блинов, 2005, с. 120].

Современные словари синонимов английского языка («тезаурусы»), включают германские, французские и греко-латинские варианты одной и той же лексической единицы, что является для образованного пользователя и указанием функционально-стилистического характера. Сегодня хорошо образованный носитель английского языка отличается от своего менее образованного соотечественника умением провести этимологическое различие в ряду синонимов германского, французского и греко-латинского происхождения и выбрать слово, соответствующее коммуникативной ситуации, определенному функциональному стилю, и это - проявление стиля языковой системы в речи.

Сравнительное изучение стилей языковых систем показывает, что стиль является результатом исторического развития языка, и одновременно помогает сделать прогноз относительно будущего тех, кто пользуется данным языком. Филологи имеют возможность влиять на стиль языка [Хазанова, 2015], формируя в ходе своих занятий языковую личность согласно своему представлению о стиле языковой системы преподаваемого языка.

\section{Библиографический список / References}

Аракин, 2005 - Аракин В.Д. Сравнительная типология английского и русского языков. M., 2005. [Arakin V.D. Sravnitelnaya tipologiya angliyskogo i russkogo yazykov [Comparative typology of English and Russian languages]. Moscow, 2005.]

Винокур, 1959 - Винокур Г.О. К истории формирования русского письменного языка в конце XVIII века (Словарь Академии Российской 1789-1794) // Избранные работы по русскому языку / Под ред. С.Г. Бархударова. М., 1959. C. 162-187. [Vinokur G.O. To the history of formation of the Russian written language at the end of the $18^{\text {th }}$ c. (Slovar' Akademii Rossiyskoy 1789-1794). Izbrannye raboty po russkomu yazyku. S.G. Barkhudarov (ed.). Moscow, 1959. Pp. 162-187. (In Russ.)]

Волынская, 2014 - Волынская А.В. Локализмы в «Словаре Академии Российской» и «Словаре русского языка XVIII века»// Российская Академия (1783-1841): язык и литература в России на рубеже XVIII-XIX веков / Под ред. В.В. Окрепилова и др. СПб., 2009. С. 173-182. [Volynskaya A.V. Localisms 
in 'Dictionary of the Russian Academy' and 'Dictionary of the Russian Language of the $18^{\text {th }}$ c.' Rossiyskaya Akademiya (1783-1841): Yazyk i literatura $v$ Rossii na rubezhe XVIII-XIX vekov. V.V. Okrepilov et al. (eds.). St. Petersburg, 2009. Pp. 173-182. (In Russ.)]

Германова, 2014 - Германова Н.В. История нормирования английского языка. Лингвокультурные основания британской нормативной грамматики. М., 2014. [Germanova N.V. Istoriya normirovaniya angliyskogo yazyka. Lingvokul'turnye osnovaniya britanskoy normativnoy grammatiki [A history of standardization of the English language. Linguocultural grounds of British normative grammar]. Moscow, 2014.]

Гухман, 1970 - Гухман М.М. Литературный язык // Общее языкознание. Формы существования, функции, история языка / Под ред. Б.А. Серебренникова. M., 1970. C. 502-548. [Gukhman M.M. Literary Language. Obshchee yazykoznanie. Formy sushchestvovaniya, funktsii, istoriya yazyka. B.A. Serebrennikov (ed.). Moscow, 1970. Pp. 502-548. (In Russ.)]

Дорошенко, 1984 - Дорошенко Е.В. Названия семиотических явлений в американском варианте английского языка (на материале словаря «Вебстер»): Дис. ... канд. филол. наук. М., 1984. [Doroshenko E.V. Nazvaniya semioticheskikh yavleniy $\mathrm{v}$ amerikanskom variante angliyskogo yazyka (na materiale slovarya «Vebster») [The names of semiotic phenomena in the American English language (based on the Webster dictionary)]. PhD theses. Moscow, 1984.]

Захарова, 2009 - Захарова Е.А. Отражение лексикографической практики «Словаря Академии Французской» в «Словаре Академии Российской» (1789-1794) // Российская Академия (1783-1841): язык и литература в России на рубеже XVIII-XIX веков / Под ред. В.В. Окрепилова и др. СПб., 2009. C. 13-25. [Zakharova E.A. Reflection of the lexicographic practice of the Dictionary of the French Academy in the Dictionary of the Russian Academy (1789-1794). Rossiyskaya Akademiya (1783-1841): Yazyk i literatura v Rossii na rubezhe XVIIIXIX vekov. V.V. Okrepilov et al. (eds.). St. Petersburg, 2009. Pp. 13-25. (In Russ.)]

Захарова, Петрова, 2002 - Захарова Е.А., Петрова З.М. Церковнославянская лексика в «Словаре Академии Российской» 1789-1794 гг. и в «Словаре русского языка XVIII века»// Словарь Академии Российской (1789-1794): B 6 т. T. 3 (3-M). M., 2002. C. 20-28. [Zakharova E.A., Petrova Z.M. Old-Slavic lexics in 'Dictionary of the Russian Academy' and 'Dictionary of the Russian Language of the $18^{\text {th }}$ c.']. Slovar' Akademii Rossiyskoy (1789-1794). In 6 volumes. Vol. 3 (Z-M). M., 2002. Pp. 20-28. (In Russ.)]

Карамзин, 1964 - Карамзин Н.М. Речь, произнесенная на торжественном собрании Императорской Российской Академии 5 декабря 1818 года // Н.М. Карамзин. Избранные сочинения в двух томах. Сост. Г. Макогоненко. М.; Л., 1964. С. 233-244. [Karamzin N.M. A speech made at the assembly in the Emperor's Russian Academy, 5 December, 1818. N.M. Karamzin. Izbrannye sochineniya $v$ dvukh tomakh. G. Makogonenko (comp.). Moscow; Leningrad, 1964. Pp. 233-244. (In Russ.)]

Малышева, 2009 - Малышева И.А. Словарь Академии Российской (1789-1794 гг.) как источник Словаря русского языка XVIII века // Российская Академия (1783-1841): язык и литература в России на рубеже XVIII-XIX веков / Под ред. В.В. Окрепилова и др. СПб., 2009. С. 159-172. [Malysheva I.A. Slovar' Akademii Rossiyskoy (1789-1794 gg.) kak istochnik Slovarya russkogo 
yazyka XVIII veka [Dictionary of the Russian Academy as a Source of Dictionary of the Russian Language of the $18^{\text {th }}$ c.]. Rossiyskaya Akademiya (1783-1841): Yazyk i literatura v Rossii na rubezhe XVIII-XIX vekov. V.V. Okrepilov et al. (eds.). St. Petersburg, 2009. Pp. 159-172. (In Russ.)]

Рождественский, Блинов, 2005 - Рождественский Ю.В., Блинов А.В. Введение в языкознание. M., 2005. [Rozhdestvenskiy Yu.V., Blinov A.V. Vvedenie v yazykoznanie [Introduction to linguistics]. Moscow, 2005.]

Рождественский, 2015 - Рождественский Ю.В. Теория риторики. М., 2015. [Rozhdestvenskiy Yu.V. Teoriya ritoriki [Theory of Rhetoric]. Moscow, 1997.]

CAP, 1789-1794 - Словарь Академии Российской 1789-1794. Электронное издание. URL: http://it-claim.ru/Projects/ESAR/SAR/PDFSAR/Framesetpdf. htm [Slovar' Akademii Rossiyskoy 1789-1794. [Dictionary of the Russian Academy]. URL: http://it-claim.ru/Projects/ESAR/SAR/PDFSAR/Framesetpdf.htm]

Ступин, 1986 - Ступин Л.П. Лексикография английского языка. М., 1986. [Stupin L.P. Leksikografiya angliyskogo yazyka [Lexicography of the English language]. Moscow, 1986.]

Успенский, 1994 - Успенский Б.А. Краткий очерк истории русского литературного языка (XI-XIX вв.). М., 1994. [Uspenskiy B.A. Kratkiy ocherk istorii russkogo literaturnogo yazyka [A brief outline of the history of the Russian literary language (XI-XIX c.)]. Moscow, 1994].

Хазанова, 2000 - Хазанова О.Э. Стилистические особенности языковых систем русского и английского языков // Проблемы лингвистики и методики преподавания иностранных языков / Под ред. И.В. Шевлягиной. М., 2000. C. 139-141. [Khazanova O.E. Stylistic features of the Russian and English language systems. Problemy lingvistiki $i$ metodiki prepodavaniya inostrannykh yazykov. I.V. Shevlyagina (ed.). Moscow, 2000. Pp. 139-141. (In Russ.)]

Хазанова, 2015 - Хазанова О.Э. Литературный текст как факт культурного отбора для целей образования // Наука и школа. 2015. № 3. С. 105-113. [Khazanova O.E. Literary text as a fact of cultural selection for education. Science and School. 2015. No. 3. Pp. 105-113. (In Russ.)]

Чернышева, 2002 - Чернышева М.И. Состав и структура Словаря Академии Российской, 1789-1794 // Словарь Академии Российской (1789-1794): В 6 т. T. 2 (Г-Ж). M., 2002. C. 12-38. [Chernysheva M.I. Composition and structure of Dictionary of the Russian Academy, 1789-1794. Slovar' Akademii Rossiyskoy (1789-1794). In 6 volumes. Vol. 2. Moscow, 2002. Pp. 12-38. (In Russ.)].

Языкознание, 1998 - Большой энциклопедический словарь «Языкознание». M., 1998. [Bol'shoy entsiklopedicheskiy slovar' «Yazykoznanie» [Comprehensive Encycopedic Dictionary 'Linguistics']. Moscow, 1998.].

Crystal, 2002 - Crystal D. The English language: A guided tour of the language. penguin books, 2002.

Johnson, 1755 - Johnson S. Dictionary of the English language: in which the words are deduced from their originals and illustrated in their different significations by examples from the best writers: To which are prefixed a history of the language, and an English grammar: in 2 vols. London, 1755. A Dictionary of the English Language: A Digital Edition of the 1755 Classic by Samuel Johnson. B. Besalke (ed.). Last modified: January 23, 2016. URL: https://johnsonsdictionaryonline.com/ downloads/ 
Johnson, 1747 - Johnson S. The Plan of a Dictionary of the English Language..., London, 1747. A Dictionary of the English Language: A Digital Edition of the 1755 Classic by Samuel Johnson. B. Besalke (ed.). Last modified: January 23, 2016. URL: https://johnsonsdictionaryonline.com/history-of-johnsons-dictionary/the-plan-of-adictionary-of-the-english-language-1747/

Lynch, 2009 - Lynch J. The lexicographer's dilemma: The evolution of «Proper» English from Shakespeare to South Park. New York, 2009.

Статья поступила в редакцию 13.08.2019

The article was received on 13.08.2019

\section{O6 авторе / About the author}

Хазанова Ольга Эдуардовна - кандидат филологических наук; доцент кафедры иностранных языков в школе Института детства, Московский педагогический государственный университет

Olga E. Hazanova - PhD in Linguistics; Associate Professor at the Department of Foreign Languages at School of the Institute of Childhood, Moscow Pedagogical State University

E-mail: olga_edwards@inbox.ru 